\title{
METODE KOOPERATIF TIPE PROBLEM POSING DALAM PEMBELAJARAN MATEMATIKA UNTUK MENINGKAKAN HASIL BELAJAR PESERTA DIDIK KELAS IX SEKOLAH MENENGAH PERTAMA
}

\author{
Dian Apriani $^{1}$, Malalina ${ }^{2}$, Rika Firma Yenni ${ }^{3}$ \\ FKIP Universitas Tamansiswa Palembang, Jl. Tamansiswa No. 261 Palembang1,2,3 \\ e-mail:_dian_apriani@unitaspalembang.ac.id
}

\begin{abstract}
ABSTRAK
Penerapan metode pengajaran sangatlah berpengaruh agar proses pembelajaran tepat dan efektif sehingga pencapaian materi pembelajaran tersampaikan secara maksimal. Tujuan dari penelitian ini adalah adalah untuk mengetahui efektifitas dari metode pengajaran kooperatif tipe Problem Posing dalam meningkatkan hasil belajar siswa pada materi bilangan berpangkat. Metode penelitian yang digunakan adalah penelitian Tindakan Kelas (PTK). Subjek penelitian adalah peserta didik kelas IX SMP Negeri 27 Palembang. Pelaksanaan penelitian ini dilakukan secara daring melalui Zoom meeting dan Whatsapp Grup. Dari hasil penelitian yang dilakukan secara daring dapat disimpulkan bahwa hasil belajar matematika siswa dapat ditingkatkan melalui metode pembelajaran kooperatif tipe Problem posing di kelas IX SMP Negeri 27 Palembang dapat dilakukan secara efektif. Adapun Nilai rata-rata hasil tes dari Siklus I dan Siklus II adalah 60,5 dan 76. Terjadi peningkatan 14,47. Persentase ketuntasan belajar pada Siklus I dan II adalah 53,1\%, dan $80,25 \%$
\end{abstract}

Kata kunci : hasil belajar, problem posing, bilangan berpangkat

\begin{abstract}
The application of teaching methods is very influential so that the learning process is appropriate and effective so that the achievement of learning materials is conveyed to the maximum. The purpose of this study was to determine the effectiveness of the Problem Posing cooperative teaching method in improving student learning outcomes in the matter of rank numbers. The research method used is Classroom Action Research (CAR). The research subjects were students of class IX SMP Negeri 27 Palembang. The implementation of this research was carried out online through Zoom meetings and Whatsapp groups. From the results of research conducted online, it can be concluded that students' mathematics learning outcomes can be improved through cooperative learning methods of Problem posing type in class IX of SMP Negeri 27 Palembang can be done effectively. The average value of the test results from Cycle I and Cycle II were 60.5 and 76. There was an increase of 14.47. The percentage of learning completeness in Cycle I and II is $53.1 \%$, and $80.25 \%$
\end{abstract}

Keywords : learning outcomes, problem posing, rank numbers

\section{PENDAHULUAN}

Matematika ialah ilmu umum yang bermanfaat untuk kehidupan manusia serta yang melandasi kemajuan teknologi modern, dan memiliki peran penting dalam bermacam disiplin ilmu dan digunakan untuk memajukan daya pikir manusia (Subchan et al., 2018). Sebab itu setiap peserta didik diharapkan dapat menjadi peka terhadap matematika sehingga mampu menghadapi tantangan masa depan. Dan diharapkan peran pendidik dalam proses belajar mengajar mampu memenuhi kebutuhan dan mengimbangi tuntutan perkembangan dunia global.

Penerapan metode pengajaran sangatlah berpengaruh agar proses pembelajaran tepat dan efektif sehingga pencapaian materi pembelajaran tersampaikan secara maksimal. Untuk mencapai tujuan agar peserta didik dapat meningkatkan hasil belajar matematika diperlukan metode pembelajaran yang tepat sehingga proses pembelajaran menjadi menarik dan pesera didik dapat belajar secara efektif. Menurut Rosliana (2019) pendidik harus memudahkan 


\section{$\pi$ (Phi)}

pembelajaran sehingga bermakna bagi peserta didik melalui inovasi pembelajaran.

Dari hasil survey dan wawancara kepada guru mata pelajaran matematika, seringkali masih mendapatkan kendala dalam merangcang metode pembelajaran dikarenakan kondisi kelas yang beragam tingkat pemahaman dan penalaran peserta didik. Untuk itu peneliti tergerak untuk menerapkan metode pembelajaran yang dapat membangkitkan keingintahuan peserta didik dalam mempelajari matematika.

Stahl (Isjoni, 2009) Pembelajaran kooperatif dapat meningkatkan hasil belajar serta menimbulkan sikap tolong menolong. Sedangkan Slavin (Isjoni, 2009) pembelajaran kooperatif adalah kegiatan pembelajaran yang dilakukan secara berkelompok dengan jumlah anggota kelompok yang kecil serta dilakukan secara kolaboratif. Dengan demikian pembelajaran kooperatif adalah pembelajaran dalam kelompok-kelompok kecil yang dapat meningkatkan hasil belajar peserta didik dan menumbuhkan sikap tolong menolong dalam belajar. Penelitian ini akan fokus pada model kooperatif tipe problem posing.

As'ari (2000) Problem Posing adalah model pembelajaran dengan merumuskan soal. Hal yang sama dinyatakan oleh Silver dan Cai (Thobroni, 2015) Problem posing adalah perumusan informasi dari pertanyaan yang dilakukan sebelum atau setelah penyelesaian pertanyaan. Hasil penelitian menunjukkan penggunaan problem posing dapat meningkatkan hasil belajar siswa (Afrianingrum \& Rahayu, 2021; Ibnatur Husnul, 2019; Indrawati \& Nurmiati, 2020)

Berdasarkan permasalahan yang telah diuraikan diatas maka tujuan dalam penelitian ini adalah untuk mengetahui efektifitas dari metode pengajaran kooperatif tipe Problem Posing dalam meningkatkan hasil belajar siswa pada materi bilangan berpangkat.

\section{METODE PENELITIAN}

Metode penelitian yang digunakan adalah penelitian Tindakan Kelas (PTK). Subjek penelitian adalah peserta didik kelas IX SMP Negeri 27 Palembang. Pelaksanaan penelitian ini dilakukan secara daring melalui Zoom meeting dan Whatsapp Grup. Hal ini dilakukan karena Pemerintah memberlakukan larangan pempelajaran tatap muka yang disebabkan oleh wabah covid-19. Teknik pengumpulan data yang digunakan adalah observasi dan dokumentasi.

Model penelitian yang digunakan dalam penelitian ini dikembangkan oleh Kenmis dan Mc Tagart. Adapub tahapan penelitian ini disajikan dalam gambar 1 berikut :

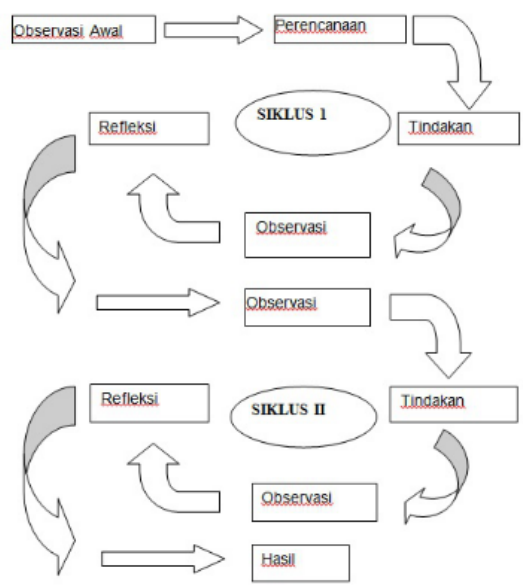

Gambar 1. Bagan Siklus PTK (Arikunto, 2017)

Gambar 1 merupakan tahapan dalam penelitian Tindakan kelas. Adapun dalam PTK terdapat empat tahapan yaitu sebagai berikut : (Arikunto, 2017)

a. Perencanaan (planning)

Perencanaan adalah Langkah yang dilakukan sebelum memulai tindakan. Adapun dalam Langkah ini guru membuat scenario pembelajaran, lembar observasi dan mendesain alat evaluasi,

b. Pelaksanaan Tindakan (Acting)

Pada tahap ini guru harus melakukan Tindakan yang telah dibuat berdasarkan scenario yang telah dibuat.

c. Pengamatan (Observing)

Pada tahap pengamatan ini, guru meminta pengamat dari luar untuk mengamati pembelajaran. Hal ini diilakukan agar hasil yang didapatkan bebas dari tindak objektif.

d. Refleksi (Reflecting)

Pada tahap ini hasil yang didapatkan dari observasi akan dievaluasi dan dianalisis. Dari hasil refleksi ini akan didapatkan kelemahan dan cara memperbaiki pembelajaran yang akan digunakan pada siklus berikutnya. 


\section{HASIL DAN PEMBAHASAN}

Penelitian ini dilaksanakan dalam 2 siklus dengan 6 kali pertemuan, yang tiap-tiap pertemuan menyediakan kompetensi dasar yang berlainan serta pada akhir setiap siklus peserta didik diberi tes tertulis berbentuk pertanyaan struktur uraian sebanyak lima pertanyaan.

Siklus I terdiri dari 4 kegiatan, yaitu: perencanaan tindakan, pelaksanaan tindakan dan observasi (pengamatan), analisis serta refleksi terhadap tindakan. Materi yang diajarkan adalah bilangan berpangkat bulat positif, dengan kompetensi dasar: Menjelaskan dan menentukan representasi bilangan bulat besar sebagai bilangan berpangkat bulat positif, dengan indikator pembelajaran: Menjelaskan konsep bilangan bulat berpangkat; Menjelaskan notasi penulisan bilangan bulat besar sebagai bilangan berpangkat bulat positif; Menentukan perbandingan bilangan berpangkat besar. Paparan materi menggunakan power point melalui aplikasi Zoom meeting.
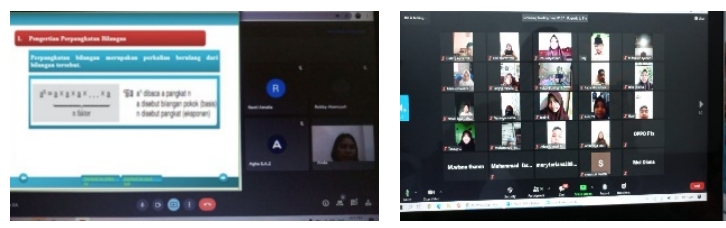

Gambar 2. Foto saat kegiatan Zoom meeting

Pada pertemuan pertama di Siklus I ini peneliti memberikan model bilangan berpangkat positif, kemudian membagi siswa dalam beberapa kelompok yang masing-masing terdiri dari 4-5 orang, dan setiap kelompok diminta untuk membaca lembar kerja siswa, yang berisi penjelasan tentang materi bilangan berpangkat bulat positif yang telah dikirim sebelumnya melalui WAG.
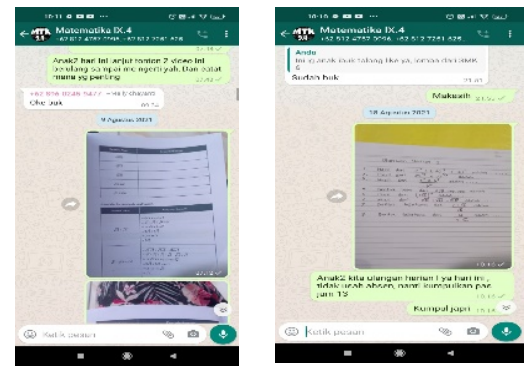

Gambar 3. Foto saat kegiatan di WA Grup
Penggunaan model pembelajaran kooperatif tipe Problem Posing bertujuan agar peserta didik mampu membuat soal berdasarkan informasi yang mereka dapatkan dari materi yang telah di sampaikan lalu mereka pikirkan tanpa batasan apapun baik terkait isinya maupun konteksnya, sehingga membuat peserta didik merasa memahami konsep dari materi tersebut. Pengetahuan dan keterampilan peserta didik diperoleh dari mengkonstruksi sendiri Ketika proses pembelajaran.

Penggunaan model pembelajaran kooperatif tipe Problem Posing akan membuat peserta didik menjadi lebih kreatif, terampil, dan mandiri. Selain itu, model pembelajaran kooperatif tipe Problem Posing membuat pembelajaran lebih bermakna dikarenakan peserta didik bekerja dan mengalami sendiri pengetahuan yang didapat. Sedangkan Peneliti hanya sebagai fasilitator dan pembimbing untuk mewujudkan potensi dan membantu peserta didik mencapai keunggulan akademik yang lebih baik.

Setelah berjalannya proses Siklus I dan II, hasil pembelajaran pada Siklus I diperoleh ratarata hasil belajar siswa 60,5. Baru 17 peserta didik yang tuntas belajar dari 32 peserta didik. Dikarenakan hasil belajar pada Siklus I belum mencapai ketuntasan secara klasikal, maka penelitian dilanjutkan pada Siklus II.

Siklus II dilaksanakan dalam 4 kali pertemuan dengan kompetensi dasar menghitung perkalian pada perpangkaan. Sebelum dilaksanakan penelitian, peneliti menyiapkan Perangkat pembelajaran dan soal-soal tes Siklus II. Nilai rata-rata tes pada Siklus II mengalami peningkatan menjadi 76. Sedangkan dari 32 siswa terdapat 26 orang siswa yang tuntas belajar dengan persentase ketuntasan belajar pada Siklus I sebesar 53,1\% dan Siklus II sebesar $80,25 \%$

Dari hasil penelitian dapat disimpulkan bahwa metode pembelajaran kooperatif tipe problem posing dapat meningkatkan hasil belajar siswa. Maka dari itu disarankan kepada pendidik dalam menerapkan metode pembelajaran kooperatif tipe problem posing terutama pada tahap kegiatan inti agar membimbing siswa dalam mengungkapkan pertanyaan-pertanyaan siswa sehingga pertanyaan dapat disampaikan 


\section{$\pi$ (Phi)}

dapat dipecahkan penyelesaiannya oleh siswa siswa.

\section{SIMPULAN}

Pelaksanaan penelitian ini dilakukan secara daring dengan kesimpulan bahwa hasil belajar matematika siswa kelas IX SMP Negeri 27 Palembang mengalami peningkatan dengan menggunakan metode pembelajaran kooperatif tipe Problem posing. Hal ini terlihat dari nilai rata-rata tes pada silkus I adalah 60,5 dan pada siklus II yaitu 76. Dari kedua sikulus ini terdapat peningkatan sebesar 14,47. Sedangkan jika dilihat dari ketuntasan belajar pada siklus I dan II sebesar $53,1 \%$, dan $80,25 \%$.

\section{UCAPAN TERIMA KASIH}

Ucapan terima kasih disampaikan kepada Lembaga Penelitian Universitas Tamansiswa Palembang yang telah memberikan hibah internal kepada peneliti.

\section{DAFTAR PUSTAKA}

Afrianingrum, S. D., \& Rahayu, T. S. (2021). Meta Analisis Efektivitas Model Pembelajaran Problem Based Laerning dan Problem Posing Terhadap Kemampuan Pemecahan Masalah dalam Pembelajaran Matematika SD. Thinking Skills and Creativity Journal, 4(1), 1. https://doi.org/10.23887/tscj.v4i1.33503

Arikunto, S. (2017). Penelitian Tindakan Kelas.

As'ari, A. R. (2000). Problem Posing untuk Peningkatan Profesionalisme Guru Matematika. Matematika, 6(1).

Ibnatur Husnul, N. R. (2019). Penerapan Metode Problem Posing Untuk Meningkatkan Kualitas Pembelajaran Matematika Ekonomi Pada Mahasiswa Jurusan Akuntansi, Unversitas Pamulang Tahun Ajaran 2017/2018. JPM: Jurnal Pendidikan Matematika, 6(1), 15. https://doi.org/10.33474/jpm.v6i1.2961

Indrawati, I., \& Nurmiati, N. (2020). Problem Posing dalam Pembelajaran Matematika SMP. Delta: Jurnal Ilmiah Pendidikan Matematika, $8(2), \quad 209$. https://doi.org/10.31941/delta.v8i2.1063

Isjoni. (2009). Cooperative Learning. Alfabeta.

Maharani, Isma Nastiti. (2011). Penerapan Model pembelajaran Problem Posing untuk meningkatkan motivasi dan hasil belajar matematika siswa kelas $\mathrm{V}$ SDN Tanjungrejo 1 Malang. UPT Perpustakaan. http://library.um.ac.id/ptk/index.php?mod= detail\&id=52839

Rosliana, I. (2019). Pengembangan LKPD Matematika dengan Model Learning Cycle 7E Berbantuan Mind Mapping. Jurnal Pengembangan Pembelajaran Matematika, 1(1), 10-22. https://doi.org/10.14421/jppm.2019.011-02

Subchan, Winarni, Mufid, M. S., Fahim, K., \& Syaifudin, W. H. (2018). Buku Guru MaTematika kelas IX. Pusat Kurikulum dan Perbukuan, Balitbang, Kemendikbud.

Thobroni. (2015). Belajar dan Pembelajaran. Ar-Ruzz Media. 